\title{
"GNOSEOLOGICAL CONCUPISCENCE" AND THE LINES OF DIVISION IN POST-CONCILIAR THEOLOGY ${ }^{1}$
}

This article is a summary of the arguments contained in the author's book Catholic Theology. It highlights the fault-lines between four of the most significant approaches to theology in the Post-Conciliar era. The author classifies these four approaches as: (1) Thomist theology, (2) Communio-style theology, (3) Concilium-style theology and (4) liberation theology.

After the Second Vatican Council ended one of the memes of the era was that Catholic scholars needed to be open to ideas that came from outside their own academies and scholarly circles. ${ }^{2}$ There is some merit in this. No one wants to foster a Catholic ghetto culture. The Catholic position has always been that the spoils of the Egyptians are legitimate plunder. However just as parents think it is good for their children to have friends from outside their immediate family

\footnotetext{
Tracey Rowland - holds the St John Paul II Chair of Theology at the University of Notre Dame (Australia). She is the author of six books, two of them on the theology of Joseph Ratzinger. She is also a member of the International Theological Commission. She holds two doctorates in theology - the civil PhD from the Divinity School of Cambridge University and the Pontifical STD from the Lateran University; e-mail: tracey.rowland@nd.edu.au, ORCID: 0000-00022349-0677.

1 This lecture is a summary of the main lines of analysis in my book Catholic Theology (London 2017). The book is part of Bloomsbury's "Doing Theology" series where each book in the series is dedicated to the subject of how theology is done in a particular Christian denomination. Hence there is Lutheran Theology, Anglican Theology, Calvinist Theology etc. The book's title does not really do justice to its content which is an attempt to show that in the Church today there are four significant ways of "doing theology" - Thomist theology, Communio-style theology, Concilium-style theology and liberation theology. Some of the paragraphs from this lecture were therefore lifted from the book.

2 A "meme" is a unit of cultural information, such as a concept, belief, or practice that spreads from person to person in a way analogous to the transmission of genes.
} 
circle, and indeed to ultimately marry someone from outside the family, most responsible parents have criteria for discerning the suitable from the unsuitable friends and fiancés. In the 1960s however no criteria were offered by the Council fathers or other ecclesial leaders for discerning good intellectual partners from bad intellectual partners, perhaps because they assumed that no faithful Catholic would be mad enough to be attracted to many of the social theories on offer in the 1960s and 70s.

Nonetheless, in volume nine of Karl Rahner's Theological Investigations, written between 1965 and 1967, Rahner observed that theologians were being confronted with numerous philosophies that cannot be synthesised with each other, and as a consequence "theology today is experiencing perforce what we may be permitted to call its "gnoseological concupiscence". ${ }^{3}$ For Rahner this meant that "every theologian will bring to his theology the particular form, the historical and fragmentary nature of his own given understanding of existence' ${ }^{4}$ Different theologians will be influenced by different philosophical schools. Rahner added to this his prediction that in the future theology's chief partner-in-dialogue will not be philosophy in a traditional sense at all, "but the "unphilosophical" pluralistic sciences and the kind of understanding of existence which they promote either directly or indirectly'. ${ }^{5}$ In an interview published some two decades later in 1985 Karl Rahner was asked whether he was of the opinion that 'European theology cannot be exported to other parts of the world, but that in Africa an independent, autonomous theology must come into being that can totally differentiate itself from our European theology'? He replied, 'Yes, of course' and added that 'in time, an African, an Asian and a South American theology must arise' ${ }^{6}{ }^{6}$ When further questioned as to whether the moral theology would be different and whether he would allow an African chief his harem, Rahner replied, 'I don't know, I don't know enough about Africa... [but] obviously, the Church doesn't need to revitalise old ethical life-styles that are now disappearing on their own'?

Rahner was prescient. He predicted the fragmentation of Catholic theology because of the wide variety of philosophical and even sociological theories to which elements of the deposit the faith would be hooked up in successive decades. He also predicted the criticisms of so-called European theology which is usually code (or what we Anglophone speakers call a "weasel word") for established

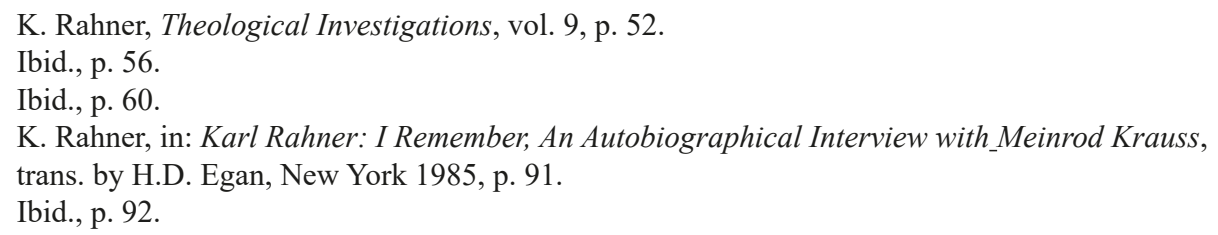


magisterial teaching, and he predicted the strange phenomenon of different moral theologies being taught in different parts of the world such that something can be regarded as a mortal sin in one diocese and merely a canon law issue in another. ${ }^{8}$ He didn't have a problem with these theological phenomena, but others did and continue to do so.

In my book Catholic Theology I suggested that today Catholic scholars can be thought of, metaphorically, as animals in a zoo. The zoo is the theology academy and the different animal species can be identified by what position they take on different issues in fundamental theology. The most important building blocks of fundamental theology are: (i) the relationship between faith and reason, and thus philosophy and theology, (ii) the relationship between nature and grace, (iii) the relationship between scripture and tradition and (iv), the relationship between history and ontology. These four building blocks or critical couplets are like spots and stripes on animals. Just as we can identify animals in a zoo by looking at their spots and stripes and thereby distinguish a leopard from a tiger, we can classify different species of Catholic theologian by looking at how they understand these critical couplets.

Today I will narrow the scope of the book to a focus on how four species of Catholic theologians understand the relationship between philosophy and theology. These four are: (i) Thomists, (ii) theologians in the Communio tradition, (iii) theologians in the Concilium trajectory and (iv) theologians who belong to one of the schools of liberation theology. The words Communio and Concilium of course refer to the two theology journals that were founded by theologians who were the leading theological advisors to the bishops at the Second Vatican Council. Concilium was founded in 1965 and Communio in 1972 after irreconcilable divisions within the Concilium group became obvious at the Concilium Congress held in Brussels in 1970.

I will begin with the Thomists. There are of course different sub-species of Thomists. You will all be familiar with Lublin Thomists and maybe you have heard of Toulouse Thomists and Fribourg Thomists, River Forest Thomists, Existential Thomists, Aristotelian Thomists, and even people who call themselves Thomists of the Strict Observance and Hillbilly Thomists. Some of these sub-species of Thomists are defined by their research priorities, others by how they understand the relationship between essence and existence, and yet others how they understand the relationship of philosophy and theology. One thing they all agree upon is that only certain types of philosophy make

8 Weasel words are words that are designed to be ambiguous and to paper-over contentious claims. Weasels are small mammals known for their sly, predatory behavior, and are related to stoats, ferrets and minks. 
suitable partners for theology. Elements of Aristotelian and Platonic philosophy are acceptable, and for most Thomists Personalist philosophy is also acceptable as a partner for theology. St. John Paul II famously developed his Lublin style Thomism by supplementing elements of classical Thomism with ideas taken from phenomenology and personalism.

However, for Thomists of all sub-species, Marxism is not acceptable as a philosophical partner to theology, nor is the Critical Theory of the Frankfurt School of Social Research so revered in the German academies, nor many of the ideas to be found in the works of Immanuel Kant and other luminaries of German Idealism or in the works of Friedrich Nietzsche and any number of post-modern schools of philosophy which deny the existence of absolute truth, of moral absolutes and of beauty that is something more than personal taste. Nor do Thomists buy into themes in Freudian psychology.

The major internal fault line among the Thomists has been between those who argue that philosophy and theology must be kept completely separate and those who think of the two disciplines existing in a more symbiotic relationship. Today the trend is to consider the two as symbiotic as was the general thrust of St. John Paul II's 1998 encyclical Fides et ratio.

An excellent book for understanding how different sub-species of Thomists in the $20^{\text {th }}$ century understood the relationship between philosophy and theology is Reason Fulfilled by Revelation: the 1930s Christian Philosophy Debates in France by Gregory B. Sadler. In his classification scheme Sadler placed the French laymen Étienne Gilson (1884-1978) and Maurice Blondel (1861-1949) as the leaders of the Christian philosophy camp, that is, those who wanted to read the relationship between philosophy and theology as intrinsic and symbiotic, while Emile Bréhir (1876-1952), Léon Brunschvicg (1869-1944), Pierre Mandonnet (1858-1936) and Fernand Van Steenberghen (1904-1993) were identified as the leaders of the circle who favoured a sharp separation of the two disciplines.

Josef Pieper was a German philosopher in the Thomist tradition who thought that the two disciplines could never be completely separated. In his book The End of Time, Pieper wrote:

It is a peculiarity of philosophical inquiry, inherent in the matter itself, that it stands from the outset in a fully-fledged "contrapuntal" relationship to theology; there is no philosophical question which, if it really wants to strike the ground intended by itself and in itself, does not come up against the primeval rock of theological pronouncements. ${ }^{9}$

9 J. Pieper, The End of Time: A Meditation on the Philosophy of History, trans. M. Bullock, New York 1954; reprinted, San Francisco 1999, p. 16. 
Pieper was influenced by Werner Jaeger's interpretation of Aristotle in Jaeger's Aristotle: Fundamentals of the History of his Development (Oxford University Press, 1934). Pieper believed that the most exciting conclusion of Jaeger's book was that behind Aristotle's metaphysics there lies the credo ut intelligam.

Pieper heavily influenced the thought of Joseph Ratzinger/Benedict XVI and as a matter of historical fact it was Josef Pieper who introduced Joseph Ratzinger and Karol Wojtyła to each other. So this brings me to the second major species of contemporary Catholic theologian - the Communio types.

The three most significant founding fathers of the Communio journal were Joseph Ratzinger, Hans Urs von Balthasar (1905-1988) and Henri de Lubac (1896-1991). As a generalisation we can say that Joseph Ratzinger's favourite philosophers were Josef Pieper, and personalists like Peter Wust (1884-1940), Martin Buber (1878-1965) and Robert Spaemann (1927-2018). He was also heavily influenced by Romano Guardini (1885-1968) who so insisted on the symbiotic relationship between philosophy and theology that his Chair at the University of Munich was called a Chair in the Philosophy of Religion and the Catholic Weltanschauung. Guardini roamed freely across the borders of philosophy and theology. De Lubac's favourite philosophers were the French laymen Gilson and Blondel. Balthasar also roamed freely across the borders of philosophy, theology and literature. He famously complained about what he called "sawdust scholasticism" or the variety of Thomism presented in many of the pre-Conciliar academies. He even wore ear-plugs to his classes on scholasticism and used the time to do translations. De Lubac once remarked to Joseph Fessio that Balthasar would sit at the back of the classroom during lectures on scholasticism reading Origen in Greek. Nonetheless, while Balthasar was repulsed by a vision of theology as a large, finite system of tightly defined scholastic concepts, such as might appeal to lawyers but not to humanists with a love of literature and music, he argued strongly for the need to retain Thomistic metaphysics and especially to retain such concepts as the analogia entis. In this context Balthasar was especially impressed by the philosophy of Ferdinand Ulrich (1931-), including Ulrich's treatment of the analogia entis, and the philosophy of Gustav Siewerth (1903-1963), especially Siewerth's account of Thomistic metaphysics. Balthasar was also favourably influenced by the thought of Erich Przywara (1889-1972) who worked extensively on the development of Thomistic metaphysics.

Andrzej Wierciński is a leading international authority on Siewerth's reading of Thomist metaphysics and has published a bilingual (English and German) edition of the Balthasar-Siewerth correspondence. This collection includes Balthasar's obituary for Siewerth in which Balthasar praises Siewerth for his hostility to 
Suárezian metaphysics. ${ }^{10}$ Balthasar also praised Siewerth for his lack of interest in a philosophy separated from theology. He wrote that for Siewerth, as for Aquinas, "Aristotle was "the last philosopher", since all that followed always-already thinks well or ill, with approval or censure, to its salvation or damnation, within the space of the Revelation that has already taken place'. He concluded: 'After Greek philosophy, all great philosophy is theology'. ${ }^{11}$

By this he meant, at least in part, that there is no neutral position from which to make judgements about theological questions. As he expressed the principle, 'theology proceeds always as a continuous dialogue between Bridegroom and Bride. The Bridegroom gives and the bride receives, and only in this acceptance of faith can the miracle of the pouring forth of the Word, which is both sower and seed, be accomplished'. ${ }^{12}$ In a full frontal assault on Kantian epistemology, Balthasar concluded that there is "no neutral standpoint outside the encounter between Bride and Bridegroom'. As a consequence, he wrote:

It is of the utmost importance to see that what is lacking [in the relationship between spirituality and theology] is not just a piece of material that can be easily incorporated into the existing structure, or else a sort of stylistic quality to be reproduced anew... The fact is that the spiritual dimension can only be recovered through the soul of man being profoundly moved as the result of his direct encounter with revealed truth, so that it is borne in upon him, once and for all, how the theologian should think and speak, and how he should not. This holds good for both the estranged disciplines, dogmatic theology and spirituality. ${ }^{13}$

Speaking directly of dogmatic theology, Balthasar further asserted that it is 'no mere connecting link between revelation and something else, such as human nature or reason or philosophy'. Rather:

Human nature and its mental faculties are given their true center when in Christ; in him they attain their final truth, for such was the will of God, the Creator of nature, from eternity. Man, therefore, in investigating the relationship between nature and supernature, has no need to abandon the standpoint of faith, to set himself up as the mediator between God and the world, between revelation and reason, or to cast himself

10 H.U. von Balthasar, in: A. Wierciński, Between Friends: The Hans Urs von Balthasar and Gustave Siewerth Correspondence 1954-1963, Konstanz 2005-2007, p. 159, fn. 4.

11 Ibid., p. 165.

12 H.U. von Balthasar, Explorations in Theology, vol. 1: The Word Made Flesh, San Francisco 1989, p. 201.

13 Ibid., p. 201. 
in the role of judge over that relationship. All that is necessary is for him to understand 'the one mediator between God and man, the man Christ Jesus (1 Tim 2:5), and to believe him in whom 'were all things created in heaven and on earth....all by him and in him' (Col: 1:16). Christ did not leave the Father when he became man to bring all creation to fulfilment; and neither does the Christian need to leave his centre in Christ in order to mediate him to the world, to understand his relation to the world, to build a bridge between revelation and nature, philosophy and theology. ${ }^{14}$

There is, in other words, no neutral space in which any scholar may stand. The desire for such neutrality is a kind of infidelity, if not, outright idolatry. It's a case of kneeling before the altar of an eighteenth century god. As Ratzinger put the idea, there is no such thing as 'pure reason', there is only 'impure reason' or 'purified reason'. 15

Because of their opposition to the ideas of Suárez and Kant the Communio theologians have a lot in common with the British-based Radical Orthodox scholars. Radical Orthodoxy is not the name of a collection of theological doctrines. It has been described as more of an intellectual sensibility. It grew up in Cambridge in the early 1990s after the High Church Anglican theologian, John Milbank, published his seminal work Theology and Social Theory: Beyond Secular Reason. The driving idea of this work is that there is no such thing as theologically neutral social theory. The leading lights of the RO circle, John Milbank, Graham Ward and Catherine Pickstock, are all High Church Anglicans, but those who have published under the RO banner include Catholics, Calvinists and Anabaptists, and a significant number of scholars have converted to the Catholic faith while studying in this circle.

Graham Ward has described Radical Orthodoxy as a project of Christian cultural criticism whose chief concern is 'unmasking the cultural idols, providing genealogical accounts of the assumptions, politics and hidden metaphysics of specific secular varieties of knowledge - with respect to the constructive, therapeutic project of disseminating the Gospel'. ${ }^{16}$ This description could equally apply to the work of many of the Communio scholars. They all believe that secularism is a bad thing, that it has its origins in the Franciscan nominalism of the fourteenth century and the subsequent destruction of a sacramental cosmology. They are also interested in showing how socalled secular scholarship carries within it hidden theological assumptions.

$14 \quad$ Ibid., p. 195.

15 J. Ratzinger, The Dignity of the Human Person: Commentary on "Gaudium et spes", in: Commentary on the Documents of Vatican II, ed. H. Vorgrimler, III, New York 1969, p. 155.

16 G. Ward, Radical Orthodoxy/and as Cultural Politics, in: Radical Orthodoxy: A Catholic Enquiry, ed. L.P. Hemming, Aldershot 2000, p. 104. 
The most significant difference between the two groups (that is, Communio scholars and RO scholars) is that some (not all) Radical Orthodoxy members take a different stance on the theological significance of gender differences from that of the Communio authors. The typical concrete issues here are the ordination of women and the moral status of homosexual practices. The Anglicans who publish under the RO banner have no opposition to the ordination of women, and some, not all, regard homosexual practices as morally unproblematic, whereas the Catholics follow the magisterial teaching of the Catholic Church on all issues, including those pertaining to gender distinctions and sexual morality.

As a generalisation, there is a tendency for RO scholars who concur with the Catholic understanding of the significance of sexual difference to "swim the Tiber", something that was psychologically easier during the pontificate of Benedict XVI who was not only a world class scholar to whom Oxbridge types could relate, but someone who shared many of the intellectual presuppositions of the RO circle.

So to summarise, both the Thomists and the Communio scholars, as well as many of the Radical Orthodoxy scholars, believe that not any philosophy is able to operate as a handmaid to theology. Some philosophies are completely unsuitable. Both the RO types and the Communio types tend to be much more Platonic than they are Aristotelian and this is in part because of their interest in Platonic conceptions of participation. They are also, along with some of the Thomists, interested in personalism. But no one in any of these three groups is of the view that theology can be hooked up with Marxism and its intellectual derivatives and no one in any of these three groups believes that social theory, indeed the entire academic discipline that calls itself sociology, is theologically neutral. This is Milbank's number 1 argument - social theory is never theologically neutral.

This brings us to the other two major species of contemporary Catholic theologian - the Concilium types and the Liberation Theology types. These types are intellectual cousins. The Concilium types are interested in correlating the faith to contemporary social movements or, to use their own academic idiom, to "re-contextualise the faith with reference to the "critical consciousness" of a given era'. In other words, their basic orientation is to begin with contemporary philosophies and social theories and to then 'correlate' or 're-contextualise' the faith to these theories. The concept of correlation was promoted by the Dominican Edward Schillebeeckx (1914-2009). The idea was to market the faith by reference to elements that were popular in the contemporary culture. For example, if liberation is a popular idea and the 'critical -consciousness' of the era is in favour of liberation, then the Catholic faith needs to be correlated to this concept and presented as a form of liberation. 
Today second-generation Schillebeeckxians whosenatural habitat is the universities of Holland and Belgium have dropped the concept of correlation and replaced it with the concept of re-contextualisation. Like correlation, re-contextualisation is all about starting with fashionable social theories and then positioning the faith in reference to them. The difference between correlation and re-contextualisation is that first generation Schillebeeckxians thought they had to correlate the faith to the culture of modernity, while the second generation Schillebeeckxians now think that the culture of modernity was flawed, that all right-thinking people are now post-moderns, and therefore Catholic theology has to be re-contextualised to the many different subcultures operating within our post-modern culture today. Whether we are talking about correlating or re-contextualising, it amounts to the same thing of giving an epistemic priority to some contemporary social theory or powerful social phenomenon such as gender-identity. In one stark statement about re-contextualisation, Schillebeeck's former student, Erik Borgman, has explained that: "what is normative, from the perspective of faith, are not Jesus' words and actions but the relationship between the words and the deeds of Jesus on the one hand and their context on the other. Believers here and now are not asked to imitate what Jesus said or did, rather they are to relate to their context as Jesus related to his'. ${ }^{17}$ This principle, of course, has enormous implications for how we understand scriptural hermeneutics and the relationship between scripture and tradition and dogmatic theology.

Of all the philosophies on the intellectual smorgasbord, one of the most influential among the Concilium network of theologians has been the Critical Theory of the Frankfurt School of Social Research. The fundamental principles of "Critical Theory" were set out by Max Horkheimer (1895-1973) in the Zeitschrift für Sozialforschung (Journal for Social Research) most of which were republished in 1968 under the title Kritische Theorie (Critical Theory). The Polish historian of Marxist theory, Leszek Kołakowski, has described Horkheimer's thought as 'permeated by the Marxist principle that philosophical, religious, and sociological ideas can only be understood in relation to the interests of different social groups (but not that everything 'in the last resort' comes down to class-interest), so that theory is a function of social life'. ${ }^{18}$ Accordingly, there are no such things as 'facts' -'perception cannot be isolated from its social genesis; both it and its objects are a social and historical product' - and 'the facts ascertained are in part determined by the collective praxis of human beings who have devised the conceptual instruments used by the investigator'. ${ }^{19}$ In short, as William L Portier

17 E. Borgman, Gaudium et spes: The Forgotten Future of a Revolutionary Document, Concilium 4 (2005), p. 54.

18 L. Kołakowski, Main Currents of Marxism, vol. 3, Oxford 1978, p. 347.

19 Ibid., p. 353. 
concluded: 'Critical Theory attempts to exploit one of the fundamental insights of the Marxist tradition...that the interpretation of any tradition likely involves systematic distortions of communication in the interests of those who have power and privilege' ${ }^{20}$ When this kind of thinking is applied to the world of theology the result is that a hermeneutic of suspicion hangs over the ideas of those who are highly educated scholars from first world countries, or at least, such people are vulnerable to criticism by intellectual opponents on the grounds that in promoting certain ideas they are merely serving some class or other personal interest.

In his article 'Theology and Praxis' published in 1973, Charles Davis, who was a huge name in British Catholic theology circles in the 1960s, but by 1973 a laicised Jesuit, described the attraction of the Frankfurt School's Critical Theory to contemporary Belgian and Dutch theologians in the following terms:

Fundamental for them as a consequence of their acceptance of the Marxist unity of theory and praxis is a conviction that the permanent self-identity of the Christian faith cannot be presupposed $[\ldots]$ They reject a theoretical system of identity $[\ldots]$ Truth does not yet exist; it cannot be reached by interpretation, but it has to be produced by change $[\ldots]^{21}$.

In the final paragraph of his article Davis pointed to the significance of this appropriation of Critical Theory with the rhetorical question: "Is theology, as Schillebeeckx says, the critical self-consciousness of Christian praxis, or is Kołakowski right when he says: "For theology begins with the belief that truth has already been given to us, and its intellectual effort consists not of attrition against reality but of assimilation of something which is ready in its entirety'.22

All Thomists and Communio scholars would agree with Kołakowski. The great majority, if not almost all Concilium and Liberation Theologians, would agree with Schillebeeckx.

When we turn finally to the territory of the liberation theologians, the bridge between them and the Concilium types is the work of Johann-Baptist Metz (1928-). Metz accused the standard magisterial theology of the 1960s of being too concerned about matters of individual salvation and not sufficiently concerned with the political dimensions of the faith. German "Political Theologians" such as Metz demanded a political interpretation of the Gospel rather than what they called an existential interpretation.

20 W.L Portier, Interpretation and Method, in: The Praxis of Christian Experience: An Introduction to the Theology of Edward Schillebeeckx, eds. R.J. Schreiter, M.C. Hilkert, San Francisco 1989.

21 Ch. Davis, Theology and Praxis, Cross Currents 23,2 (1973), pp. 154-68 (167).

22 Ibid., p. 167. 
The Liberation Theologians take up this theme. According to Jose Comblin, 'faith does not consist in [the] intellectual acceptance of specific truths drawn from the Bible. Faith consists in recognizing God's plan, or the coming of the kingdom of God. It is a matter of recognizing the march of the people of God in our times'. ${ }^{23}$ To do this work of 'recognising the march of the people of God in our times' the liberation theologians turn to social theory as an intellectual partner for theology.

According to Michael R Candelaria, one of the intellectual historians of liberation theology:

A basic theological fundamentum of Liberation Theology in general, is the unitary view of history, una sola historia. This idea affirms the unity of salvation and liberation, redemption and earthly progress, the sacred and the profane. Reality is one. There is no supernatural realm outside of and above the natural realm of human history. ${ }^{24}$

For [Juan] Segundo, [one of the big names in liberation theology] secularisation moves humanity closer to total human liberation. In his mind, secularisation is a 'central postulate of the Christian message'. Seen in terms of theology's task, secularization means shifting the focus of our intellectual endeavours from the realm of the heavenly to the realm of the earthly [...]. At bottom, secularisation means that everything in the Church must be translated from 'religious' terms into man's tasks in history. ${ }^{25}$

Another common thread running through all the versions of liberation theology is that they give priority to praxis over theory, to ethos over logos. Doctrine and dogmatic theology are almost regarded as obscene ideas. This is the exact opposite of the position taken by Romano Guardini who argued that logos must always precede ethos - a position with which Joseph Ratzinger strongly concurred.

The Argentinian strain of Liberation Theology goes by the name of "People's Theology". It is said to be Peronist in inspiration rather than Marxist, and the adjective "Peronist" is a reference to the social ideas of Juan Peron (1895-1974) who was an Argentinian general and politician.

One of the most interesting articles on this subject of People's Theology is Juan Carlos Scannone's 'El papa Francisco y la telogia del pueblo' published in the journal Razón y Fe. ${ }^{26}$ Scannone is a Jesuit and a former teacher of Pope Francis. In this paper Scannone claims that not only is Pope Francis a practitioner of "People's Theology" but that his favourite four principles - time is greater

\footnotetext{
23 Ibid., p. 83.

24 M.R. Candelaria, Popular Religion and Liberation: The Dilemma of Liberation Theology, New York 1990, p. 110.

25 Ibid., p. 110.

26 J.C. Scannone, El papa Francisco y la telogia del pueblo, Razón y Fe 1395 (2014), pp. 31-50.
} 
than space, unity prevails over conflict, reality is more important than ideas, and the whole is greater than the parts - actually come from a letter of the nineteenth century Argentinian dictator, Juan Manuel de Rosas (1793-1877) sent to another Argentinian caudillo, Facundo Quiroga (1788-1835), in 1834. These principles have their own section in Pope Francis's Apostolic Exhortation Evangelii Gaudium and references to one or other of them can be found scattered throughout his other papal documents. Many people have tried to explain these principles by reference to different philosophies but according to Scannone their foundations are in the field of political strategy, not philosophy.

A sub-species of Liberation Theology is Feminist Liberation Theology. A snapshot summary of the methodology of feminist theologians was offered by Gloria L Schaab in the journal Theological Studies in 2001. Schaab wrote:

Critique in the feminist theological process begins with a "hermeneutics of suspicion" that is wary of underlying prejudices and presuppositions that exclude women's perspectives. During this stage of the process, oppressive texts are demythologised, exclusive male symbolism for the divine is exposed, dualisms of body and spirit are rejected, and hierarchical understandings of power are destabilised. Having thus exposed the insufficiency of the biblical and theological tradition at face value, the process moves below the surface of texts and beyond traditional sources to a retrieval of women's experiences found between the lines, in the silence, and from alternative sources. In the movement to (re) construction, feminist theology enters in to the task of reshaping key religious symbols, especially those that are problematic from the Christian feminist perspective, through strategies elaborated from the critiques outlines above. Among such concepts are Christology and soteriology, particularly as regards the maleness of Jesus. Posing particular difficulty is the doctrine of the Cross, with its conflicting symbolism of victimization and violence, as well as empowerment and solidarity. Ultimately the mystery of God articulated in predominately male imagery and Trinitarian symbolism based upon hierarchical gender models is fundamentally challenged as subversive to the reality of woman as imago Dei and imago Christi. ${ }^{27}$

While there are different strands in Feminist Theology (for example, liberal, Marxist, essentialist, constructivist, structuralist, post-structuralist, first-wave, second-wave, third-wave, fourth-wave and eco-feminist), Schaab's description above does identify the typical hallmarks of the genre. Feminist hermeneutics have been a powerful element in what Rahner identified as the post-Conciliar "gnoseological concupiscence".

27 G.L. Schaab, Feminist Theological Methodology: Toward a Kaleidoscopic Model, Theological Studies 62 (2001), pp. 341-365. 
In conclusion, from all the above, it may be argued that the fundamental question is: does Christ position philosophy, ethics and cultural forms or do they position Christ? Or to repeat the question of Charles Davis: 'Is theology, as Schillebeeckx says, the critical self-consciousness of Christian praxis, or is Kołakowski right when he says: "For theology begins with the belief that truth has already been given to us, and its intellectual effort consists not of attrition against reality but of assimilation of something which is ready in its entirety"?

How one answers these two questions, which essentially are just one question expressed in two different ways, will determine whether one is more at home in the circles of Thomist and Communio scholars, or more at home in the world of Concilium scholars and liberation theologians. Beneath this question is the issue of the relationship of logos to ethos and a whole raft of metaphysical presuppositions.

\section{BIBLIOGRAPHY}

Balthasar H.U. von, Explorations in Theology, vol. 1: The Word Made Flesh, San Francisco 1989.

Balthasar H.U. von, in: A. Wierciński, Between Friends: The Hans Urs von Balthasar and Gustave Siewerth Correspondence 1954-1963, Konstanz 2005-2007.

Borgman E., Gaudium et spes: the Forgotten Future of a Revolutionary Document, Concilium 4 (2005), p. 54.

Candelaria M.R., Popular Religion and Liberation: The Dilemma of Liberation Theology, New York 1990.

Davis Ch., Theology and Praxis, Cross Currents 23,2 (1973), pp. 154-68 (167).

Kołakowski L., Main Currents of Marxism, vol. 3, Oxford 1978.

Pieper J., The End of Time: A Meditation on the Philosophy of History, trans. M. Bullock, New York 1954; reprinted San Francisco 1999.

Portier W.L., Interpretation and Method, in: The Praxis of Christian Experience:

An Introduction to the Theology of Edward Schillebeeckx, eds. R.J. Schreiter, M.C. Hilkert, San Francisco 1989.

Rahner K., Theological Investigations, vol. 9, London 1972.

Rahner K., in: Karl Rahner: I Remember, An Autobiographical Interview with Meinrod Krauss, trans. by H.D. Egan, New York 1985.

Ratzinger J., The Dignity of the Human Person: Commentary on "Gaudium et spes", in: Commentary on the Documents of Vatican II, ed. H. Vorgrimler, III, New York 1969. Rowland T., Catholic Theology, London 2017.

Scannone J.C., El papa Francisco y la telogia del pueblo, Razón y Fe 1395 (2014), pp. $31-50$. 
Schaab G.L., Feminist Theological Methodology: Toward a Kaleidoscopic Model, Theological Studies 62 (2001), pp. 341-365.

Ward G., Radical Orthodoxy/and as Cultural Politics, in: Radical Orthodoxy: A Catholic Enquiry, ed. L.P. Hemming, Ashgate 2000.

Keywords: gnoseological concupiscence, thomism, Communio theology, Concilium theology, liberation theology

„POŻĄDLIWOŚĆ POZNAWCZA” I LINIE PODZIAŁU W TEOLOGII POSOBOROWEJ

\section{Streszczenie}

Artykuł stanowi zwięzłą prezentację treści, które autorka przedstawiła w książce Catholic Theology. W tekście naszkicowane zostają główne nurty teologii epoki posoborowej. Autorka zarysowuje granice pomiędzy alternatywnymi podejściami, wskazując na ich cechy charakterystyczne. Cztery omawiane nurty teologiczne to teologia tomistyczna, teologia nurtu Communio, teologia nurtu Concilium oraz teologia wyzwolenia.

Słowa kluczowe: pożądliwość poznawcza, tomizm, teologia Communio, teologia Concilium, teologia wyzwolenia 